\title{
Enhanced single-cell oil production by cold shock in cyanobacterial cultures
}

\author{
Maria Isabel Queiroz ${ }^{1}$ Mariana Manzoni Maroneze ${ }^{2}$ Adriana Gonçalves da Silva Manetti ${ }^{1}$ \\ Juliana Guerra Vieira ${ }^{1}$ Leila Queiroz Zepka ${ }^{2}$ Eduardo Jacob-Lopes ${ }^{2 *}$ C
}

${ }^{1}$ Escola de Química de Alimentos, Universidade Federal de Rio Grande (FURG), Rio Grande, RS, Brasil.

${ }^{2}$ Departamento de Ciência e Tecnologia dos Alimentos, Universidade Federal de Santa Maria (UFSM), 97105-900, Santa Maria, RS, Brasil. E-mail: jacoblopes@pq.cnpq.br. "Corresponding author.

ABSTRACT: The aim of this research was to evaluate the enhanced single-cell oil production by cold shock in Aphanothece microscopica Nägeli using dairy processing wastewater as culture medium. The study focused on (i) temperature optimization for biomass production, (ii) cold shock application to induce lipids biosynthesis and (iii) determination of fatty acids profile under different conditions. Results indicated that temperature of $20^{\circ} \mathrm{C}$ was the best condition in terms of kinetics parameter, reaching biomass productivities of $160.25 \mathrm{mg} / \mathrm{L}$.h Under these conditions, a lipid content of $12.65 \%$ was also observed, resulting in a lipid productivity of $20.27 \mathrm{mg} / \mathrm{L} . \mathrm{h}$. Additionally, the $0^{\circ} \mathrm{C}$ cold shock was the most efficient in increasing intracellular lipid content, reaching $28.4 \%$ in dry weight. Cold shocks also showed influence on the saturation of fatty acid composition, where the saturated fatty acids decreased, and the monounsaturated and polyunsaturated fatty acids increased by increasing the cold application. Thus, the use of cold shocks indicates to be a key condition for improving the prospects of efficient single-cell oils production.

Key words: Aphanothece microscopica Nägeli, dairy wastewater, lipid, microalgae, temperature stress.

Aumento da produção de óleos unicelulares através de choques de frio em culturas de cianobactérias

RESUMO: $O$ objetivo deste trabalho foi avaliar o aumento da produção de óleos unicelulares por Aphanothece microscopica Nägeli utilizando água residuária de processamento de laticínios como meio de cultura. O estudo concentrou-se na (i) otimização da temperatura para produção de biomassa, (ii) aplicação de choque frio para induzir a biossíntese de lipídios e (iii) determinação do perfil de ácidos graxos sob diferentes condições. Os resultados indicam que a temperatura de $20^{\circ} \mathrm{C}$ foi a melhor condição em termos de parâmetros cinéticos, atingindo produtividades de biomassa de 160,25mg/L.h. Nesta condição também foi observado um teor lipídico de 12,65\%, o que resultou em uma produtividade lipídica de $20,27 \mathrm{mg} / \mathrm{L}$.h. Além disso, o choque frio de $0^{\circ} \mathrm{C}$ foi o mais eficiente para aumentar o conteúdo lipidico intracelular, que atingiu $28,4 \%$ em peso seco. Os choques frios também mostraram influência na saturação da composição de ácidos graxos, em que os ácidos graxos saturados diminuíram, e os ácidos graxos monoinsaturados e poli-insaturados ampliaram com o aumento da aplicação de frio. Assim, o uso de choques frios indica ser uma condição chave para melhorar as perspectivas de produção eficiente de óleos unicelulares. Palavras-chave: Aphanothece microscopica Nägeli, águas residuais de leite, lipídios, microalgas, estresse de temperatura.

\section{INTRODUCTION}

Increasing global demands for food and biofuels, depletion of fossil resources and climate change are the major reasons to search for alternative and sustainable renewable biofuels (ZHOU et al., 2014). Microalgae oils are promising alternatives to oilseeds sources commonly used, due to their unique characteristics, such as feasibility of growing on non-arable lands, tolerance to diverse environments, fast proliferation and high oil accumulation (BREUER et al. 2015).

Particularly, cyanobacteria are more potential than eukaryotic microalgae for use as biocatalyst in algae-based process, since these microorganisms are robust, have simple nutritional requirements, and can use up to three metabolic pathways to obtain energy, i.e. photosynthesis, respiration, and nitrogen fixation (FAY, 1983; QUEIROZ et al.2011). During their long evolutionary history, cyanobacteria have undergone several structural and functional modifications responsible for their versatile physiology and wide ecological tolerance (HERRERO et al. 2001).

Conversely, according to GRIFFITHS \& HARRISON (2009) cyanobacteria generally have lower lipid content in dry biomass (5-13\%) compared to eukaryotic microalgae (13-31\%). However, 
several studies reported the possibility to induce the synthesis of single-cell oils (QUEIROZ et al. 2011; XU \& BOEING 2014; BREUER et al. 2015). This can occur by three possible strategies: genetic engineering, transcription factor engineering and biochemical engineering approaches. Biochemical engineering strategy is currently the most widely employed among them, which is based on applying physiological stresses to improve lipid content in the cells, where this can reach up to $50 \%$ of dry biomass (SUBHASH et al. 2014).

Temperature is a physical stress that can be optimized in order to maximize lipid synthesis, and, thus increase the viability of biofuel production from microalgae. An inherited disadvantage of the physiological stress is associated with reduced cell division and, as lipids are intracellular products, overall lipid productivity is directly affected for biomass productivity (QUEIROZ et al. 2011). As an alternative, a two-stage process could be used, where, at first, the cultures are subjected to favorable growth conditions and then to a stress condition in order to increase lipid production (RAS \& STEYER, 2013). Several studies have examined the use of low temperatures as a tool to optimize the single-cell oil production (SUBHASH et al., 2014; WANG et al., 2016; CHAISUTYAKORN \& PRAIBOON, 2018), where positive results were reported.

The use of low-cost feedstock production also plays an important role in biofuel production from algae commercialization. In this sense, the heterotrophic cultivation with wastewater as culture medium may offer an inexpensive alternative to phototrophic cultivations, which are totally dependent of light energy and carbon dioxide. Dairy industry is one of the most important world economic activity. In these industries, it is estimated that on average 159L of water is necessary for $1 \mathrm{~L}$ of processed milk, resulting in a significant volume of wastewater (WILLERS et al., 2014). These agro-industrial wastes have a high concentration of organic matter, nitrogen, phosphorus and others minority nutrients, which makes it suitable for supporting microalgae heterotrophic growth. Furthermore, these wastes are potentially available on a large scale, and can generate biomass with a competitive cost (QUEIROZ et al., 2013).

In this regard, the objective of this research is to evaluate the enhanced single-cell oil (SCO) production by cyanobacteria using dairy processing wastewater as culture medium. The study focused on the optimization of cultivation temperature, in the cold shock application to induce lipids biosynthesis and in the fatty acids composition analysis.

\section{MATERIALS AND METHODS}

\section{Microorganisms and culture media \\ Axenic cultures of Aphanothece} microscopica Nägeli (RSMan92) were originally isolated from the Patos Lagoon estuary, from the state of Rio Grande do Sul, Brazil (32 $\left.01^{\prime} \mathrm{S}-52^{\circ} 05^{\prime} \mathrm{W}\right)$. Stock cultures were propagated and maintained in synthetic BG11 medium (RIPPKA \& DERUELLES, 1979). The incubation conditions used were $25^{\circ} \mathrm{C}$, photon flux density of $30 \mu \mathrm{mol} . \mathrm{m}^{-2} \mathrm{~s}^{-1}$, and a photoperiod of $12 \mathrm{~h}$.

\section{Wastewater}

Wastewater used in the experiments was obtained from the dairy processing industry (Pelotas, RS, Brazil). The wastewater was collected from the discharge point of the equalization tank over a period of six months, and analyzed for $\mathrm{pH}$, total nitrogen (N-TKN), chemical oxygen demand (COD), ammonium $\left(\mathrm{NH}^{+1}\right)$, total phosphorus $\left(\mathrm{P}-\mathrm{PO}_{4}^{-3}\right)$, alkalinity, oils and greases, calcium, hardness, total solids (TS), soluble solids (SS), fixed solids (FS) and volatile solids (VS) following the Standard Methods for the Examination of Water and Wastewater (APHA, 1989). Results are shown in table 1 . The carbon/nitrogen ratio $(\mathrm{C} / \mathrm{N})$ and nitrogen/phosphorous ratio (N/P) were calculated through COD, N-TKN and $\mathrm{P}-\mathrm{PO}_{4}{ }^{-3}$.

\section{Bioreactor configuration}

Measurements were made in a bubble column bioreactor. The system was built of borosilicate glass and had an external diameter of $10 \mathrm{~cm}$ and height of $100 \mathrm{~cm}$, resulting in a height/ diameter $(\mathrm{h} / \mathrm{D})$ ratio equal to 10 , and a nominal working volume of $4.5 \mathrm{~L}$. Reactor dispersion system consisted of a $1.5 \mathrm{~cm}$ diameter air diffuser located in the center of the column. The airflow was monitored by flow meter (KI-Key Instruments).

\section{Obtaining the kinetic data in experimental bioreactors}

The experiments were carried out in bioreactors operating in a batch mode, fed with $4.5 \mathrm{~L}$ of dairy processing wastewater. The experimental conditions were as follows: initial cell concentration of $200 \mathrm{mg} / \mathrm{L}, \mathrm{pH}$ adjusted to 7.6 , isothermal reactor operating at temperatures of 10,20 and $30^{\circ} \mathrm{C}$, with absence of light and continuous aeration of $1 \mathrm{VVM}$ (air volume per culture volume/min.).

To study the effects of cold shocks, an integrated sequential two-stage algae culture system 
Table 1 - Composition of wastewater from the dairy processing industry.

\begin{tabular}{|c|c|}
\hline Parameter & Average value \\
\hline $\mathrm{pH}$ & $9.05 \pm 0.18$ \\
\hline N-TKN (mg/L) & $39.60 \pm 15.13$ \\
\hline COD (mg/L) & $2193.33 \pm 2193.3$ \\
\hline $\mathrm{N}-\mathrm{NH}_{4}{ }^{+}(\mathrm{mg} / \mathrm{L})$ & $3.9 \pm 2.36$ \\
\hline $\mathrm{P}_{-} \mathrm{PO}_{4}^{-3}(\mathrm{mg} / \mathrm{L})$ & $10.06 \pm 3.09$ \\
\hline Alkalinity (mg/L) & $619.30 \pm 62.7$ \\
\hline Oils and Greases (mg/L) & $3.75 \pm 0.64$ \\
\hline Calcium (mg/L) & $143.33 \pm 4.0$ \\
\hline Hardness (mg/L) & $40.65 \pm 8.9$ \\
\hline $\mathrm{TS}(\mathrm{mg} / \mathrm{L})$ & $2725 \pm 645.88$ \\
\hline $\mathrm{SS}(\mathrm{mg} / \mathrm{L})$ & $358.33 \pm 112.32$ \\
\hline FS (mg/L) & $1192.5 \pm 821.87$ \\
\hline VS (mg/L) & $1532.5 \pm 565.9$ \\
\hline $\mathrm{C} / \mathrm{N}$ & $31 \pm 6.42$ \\
\hline $\mathrm{N} / \mathrm{P}$ & $5.7 \pm 3.85$ \\
\hline
\end{tabular}

was developed. The first stage was responsible for biomass production, which was cultivated at optimum temperature (previously defined) in order to obtain a high productivity of biomass, followed by a second bioreactor capable of inducing lipid biosynthesis, increasing the natural content present in the cell through cold shock of 0,5 and $10^{\circ} \mathrm{C}$, for residences times of $8,16,24$ and $32 \mathrm{~h}$. The experiments were performed twice and duplicate for each operational mode. Therefore, kinetic data refer to the mean value of four repetitions.

\section{Sampling and analytical methods}

In the first stage, samples were collected every $2 \mathrm{~h}$ during the growth phase of microorganism and in the second stage every $8 \mathrm{~h}$, during the growth phase of microorganism. These samples were evaluated for cell biomass, $\mathrm{pH}$ dynamics and consumption of organic carbon and total nitrogen.

Cell concentration was gravimetrically evaluated by filtering $10 \mathrm{~mL}$ of culture medium through a $0.45 \mu \mathrm{m}$ membrane filter (Millex $\mathrm{FG}^{\circledR}$ ), drying at $60^{\circ} \mathrm{C}$ until constant weight.

The organic carbon concentration was expressed in terms of chemical oxygen demand (COD) and analyzed according to the closed reflux colorimetric method. Total nitrogen was determined by Kjeldahl method, and the total phosphorus was determined by the spectrophotometric molybdovanadate method (APHA, 1989).
Biomass data were used to calculate biomass productivity $\left[\mathrm{P}_{\mathrm{X}}=\left(\mathrm{X}_{\mathrm{i}}-\mathrm{X}_{\mathrm{i}-1}\right)\left(\mathrm{t}_{\mathrm{i}}-\mathrm{t}_{\mathrm{i}-1}\right)^{-1}, \mathrm{mg} /\right.$ L.h], maximum specific growth rate $\left[\ln \left(\mathrm{X}_{i} / \mathrm{X}_{0}\right)=\right.$ $\left.1_{\max } . t, 1 / \mathrm{h}\right]$, and the generation time $\left[\operatorname{tg}=0.693 / 1_{\max }\right.$, $\mathrm{h}$ ], where $\mathrm{X}_{0}$ is the initial biomass concentration, $X_{i}$ is the biomass concentration at the time $t_{i}$ and $\mathrm{X}_{\mathrm{i}-1}$ is the biomass concentration at the time $t_{\mathrm{i}-1}, \mathrm{t}$ is the residence time, and $1_{\max }$ is the maximum specific growth. The organic carbon and total nitrogen were used to calculate the substrate yield coefficient $\left(\mathrm{Y}_{\mathrm{x} / \mathrm{S}}\right.$ $\left.=\mathrm{dX} / \mathrm{dS}, \mathrm{mg}_{\text {biomass }} / \mathrm{mg}_{\text {substrate }}\right)$, where $\mathrm{S}_{0}$ is the initial organic carbon concentration or initial total nitrogen $(\mathrm{mg} / \mathrm{L}), \mathrm{S}$ is the organic carbon concentration or total nitrogen concentration $(\mathrm{mg} / \mathrm{L})$ and $\mathrm{t}$ is the time $(\mathrm{h})$.

The lipid fraction was extracted from the biomass by the modified Bligh and Dyer (1959) method, using the ratio between methanol, chloroform and distilled water of 2:1:0.8 (v/v/v) and quantified gravimetrically.

The method of HARTMAN \& LAGO (1976) was used to saponify and esterify the dried lipid extract to obtain the fatty acid methyl esters (FAME). The methylated samples were analyzed using a gas chromatographic instrument equipped with a flame ionization detector (GC-FID), Varian 3400CX gas chromatograph (Palo Alto, CA, USA). An aliquot of $1 \mu \mathrm{L}$ of the sample was injected into the injector in split mode. The carrier gas was hydrogen under constant pressure of 20psi. The FAME were separated using a capillary column, SP-2560 Supelco 
(Bellefonte, PA, USA, $100 \mathrm{~m} \times 0.25 \mathrm{~mm} \times 0.20 \mu \mathrm{m}$ ). FAME were identified by comparing the retention times with the authentic standards from FAME Mix37 (P/N 47885-U, Sigma-Aldrich) and quantified through area normalization using software T2100p Chromatography Station (Plus Edition) v9.04.

\section{RESULTS}

\section{Biomass production}

Temperature is one of the major factors controlling the multiplication of cyanobacteria, since these microorganisms do not have mechanisms to control its internal temperature (TOMASELLI et al. 1988). In this sense, table 2 shows the growth parameters at different temperatures.

Among temperatures tested, the cultivation at $30^{\circ} \mathrm{C}$ favored the biomass production, where the highest maximum cell biomass $(1045 \mathrm{mg} / \mathrm{L})$ were reported. However, a high cell residence time (12h) was required, which resulted in low values of maximum specific growth rate and biomass productivity of $0.25 \mathrm{~h}^{-1}$ and $70.42 \mathrm{mg} /$ L.h, respectively. In the experiments conducted at $10^{\circ} \mathrm{C}$, the lowest value for specific growth rate $\left(0.12 \mathrm{~h}^{-1}\right)$ and the highest value for the generation time (5.78h) were observed, demonstrating that decrease in temperature negatively affects cell growth. Conversely, at $20^{\circ} \mathrm{C}$, the microorganism reached a maximum cell biomass of $841 \mathrm{mg} / \mathrm{L}$ in a residence time of 4 hours, which showed the highest maximum specific growth rate $\left(0.36 \mathrm{~h}^{-1}\right)$ and biomass productivity $(160.25 \mathrm{mg} / \mathrm{L} . \mathrm{h})$.

Similarly, as occurred with cell growth, the substrate yield coefficients greatly changed as a function of temperature. The best performance was at $20^{\circ} \mathrm{C}$, where, the conversion of organic matter (COD) and nitrogen (NTK) into microalgal biomass were $0.87 \mathrm{mg}_{\text {biomass }} / \mathrm{mg}_{\mathrm{DQO}}$ and $101.7 \mathrm{mg}_{\text {biomass }} / \mathrm{mg}_{\mathrm{NTK}}$, respectively.

The main interest in modifying the environmental conditions of the system is changing the biochemical composition of microalgal biomass. All these efforts aim to maximize the lipid productivity and reduce production costs, in order to enable the algal biotechnology for biofuel production. With this in mind, the lipid composition and lipid productivity at different temperatures are presented in table 3 .

The lipid content obtained for different temperatures indicated that the highest lipid percentage $(16.0 \%)$ occurs at $10^{\circ} \mathrm{C}$, but, in terms of lipid productivity, the best performance $(20.27 \mathrm{mg} /$ L.h) was observed at $20^{\circ} \mathrm{C}$. At the same time, an inverse behavior occurs with the protein fraction, where the protein content increased with the increase in temperature (data not shown for brevity).

\section{Enhanced lipid production}

In order to improve the potential of microalgae biodiesel, there is a need for the development of a process that combines appropriate productivity biomass and lipid content (QUEIROZ et al. 2011). In this sense, a two-stage culture with initial optimization of biomass and final optimization of lipid content may thus be the best strategy to improve the volumetric lipid yield. In this regard, Figure 1 shows the lipid content of experiments that were cultivated at $20^{\circ} \mathrm{C}$, and subsequently subjected to cold shock of 0,5 and $10^{\circ} \mathrm{C}$.

Table 2 - Kinetic parameters for process in different temperatures.

\begin{tabular}{|c|c|c|c|}
\hline \multirow[t]{2}{*}{ Parameter } & \multicolumn{3}{|c|}{ 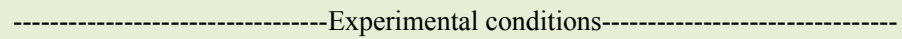 } \\
\hline & $10^{\circ} \mathrm{C}$ & $20^{\circ} \mathrm{C}$ & $30^{\circ} \mathrm{C}$ \\
\hline $\mathrm{X}_{\max }(\mathrm{mg} / \mathrm{L})$ & 355 & 841 & 1045 \\
\hline RT (h) & 4 & 4 & 12 \\
\hline GT (h) & 5.78 & 1.92 & 2.06 \\
\hline$\mu_{\max }\left(\mathrm{h}^{-1}\right)$ & 0.12 & 0.36 & 0.25 \\
\hline $\mathrm{Y}_{\mathrm{X} / \mathrm{s}}\left(\mathrm{mg}_{\text {biomass }} / \mathrm{mg}_{\mathrm{DQO}}\right)$ & 0.67 & 0.89 & 0.56 \\
\hline $\mathrm{Y}_{\mathrm{X} / \mathrm{S}}\left(\mathrm{mg}_{\text {biomass }} / \mathrm{mg}_{\mathrm{NTK}}\right)$ & 21.21 & 101.7 & 44.52 \\
\hline Px (mg/L.h) & 38.75 & 160.25 & 70.42 \\
\hline
\end{tabular}

$\mathrm{X}_{\max }$ : maximum cell biomass; RT: residence time $(\mathrm{h})$; GT: generation time $(\mathrm{h}) ; \mu_{\text {máx }}$ : maximum specific growth rate $\left(\mathrm{h}^{-1}\right)$; $\mathrm{Y}_{\mathrm{X} / \mathrm{s}}$ : substrate yield coefficient; $\mathrm{P}_{\mathrm{X}}$ : biomass productivity (mg/L.h). 
Table 3 - Lipid composition and lipid productivities at different temperature conditions.

\begin{tabular}{|c|c|c|c|}
\hline \multirow[t]{2}{*}{ Parameter } & \multicolumn{3}{|c|}{ 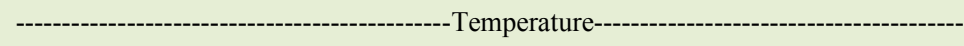 } \\
\hline & $10^{\circ} \mathrm{C}$ & $20^{\circ} \mathrm{C}$ & $30^{\circ} \mathrm{C}$ \\
\hline Lipid content (\%wt) & $16.0 \pm 2.61$ & $12.65 \pm 2.06$ & $10.87 \pm 0.90$ \\
\hline Lipid productivity (mg/L.h) & $5.4 \pm 0.00$ & $20.27 \pm 0.00$ & $7.65 \pm 0.00$ \\
\hline
\end{tabular}

The enhanced lipid production through cold shock showed a significant increase in intracellular lipid content, which reached $28.4,27.6$ and $23.0 \%$ for shocks of 0,5 and $10^{\circ} \mathrm{C}$ in $24 \mathrm{~h}$. However, the highest impact of temperature shocks was in the lipid productivity increase, especially with shock of $0^{\circ} \mathrm{C}$, which resulted in an increase of $124.5 \%$ compared to the cultivation at $20^{\circ} \mathrm{C}$ without cold shock. After 24 hours in cold shock, a decrease in lipid content was observed at all temperatures tested. Since triacylglycerides are abundant storage products and can be easily catabolized to provide metabolic energy, probably they are being used to maintain cellular metabolism. One of the most commonly observed changes in cyanobacteria biomass induced by the temperature is the change in algae fatty acid composition, as shown in figure 2 .

\section{DISCUSSION}

In general, each microalgae species is characterized by an optimal growth temperature. Results of this study showed that the temperature of $20^{\circ} \mathrm{C}$ was the best condition in terms of kinetics parameters for heterotrophic cultivation of $A$. microscopica Nägeli, as showed in table 2. In this condition, a short adaptation stage $(\mathrm{GT}=1.92 \mathrm{~h})$ was observed, which is a characteristic of cultivation with ideal growth conditions. Conversely, at $10^{\circ} \mathrm{C}$ a generation time of $5.78 \mathrm{~h}$ was observed, about $301 \%$ greater than $20^{\circ} \mathrm{C}$, suggesting a cellular stress condition. Despite the highest cellular concentration reported at $30^{\circ} \mathrm{C}$, the best value of biomass productivity was registered at $20^{\circ} \mathrm{C}$, mainly due to the

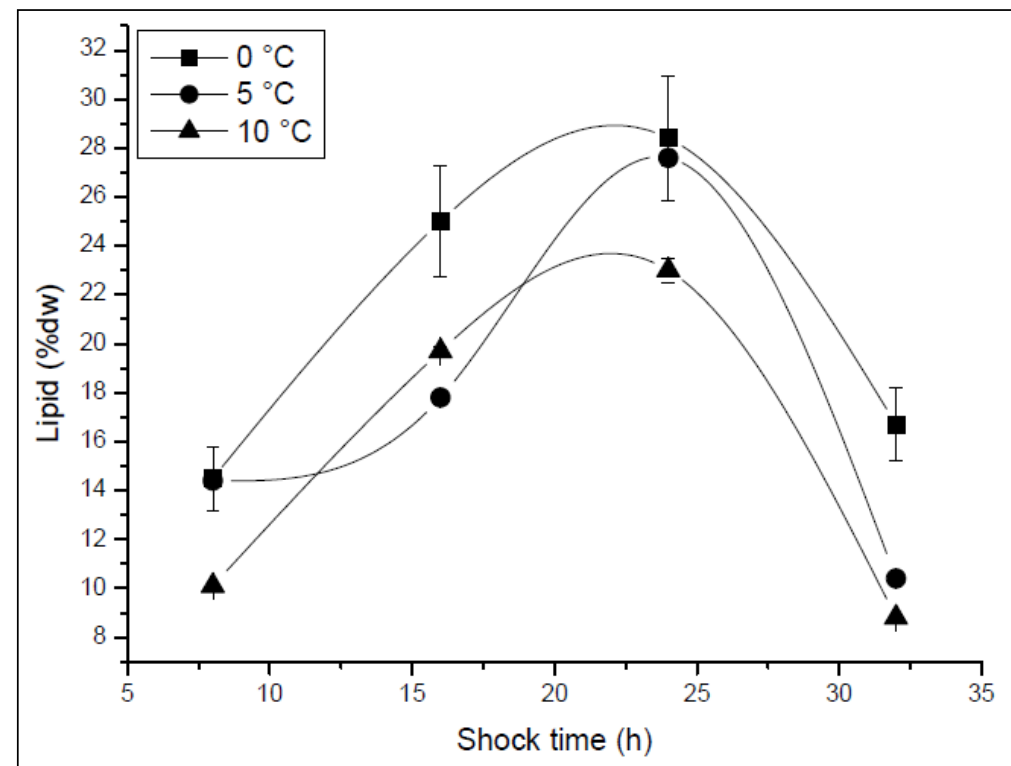

Figure 1 - Lipids content in Aphanotece microscopia Nägeli at different temperatures and shock time. 


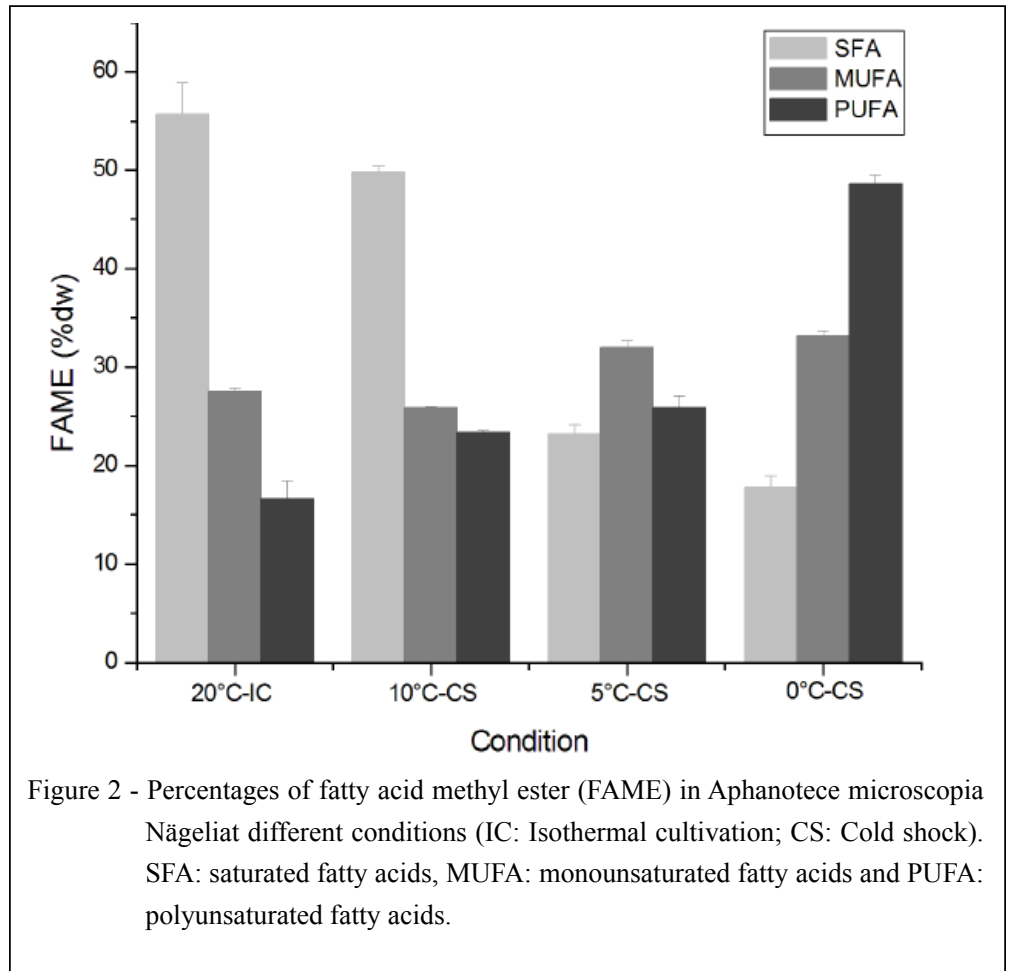

low residence time required to reach the maximum cell concentration.

It's known that ideal growth temperatures can diverge when studying one same species, as observed in the literature (RAS \& STEYER , 2013). In previous studies (QUEIROZ et al., 2011), we reported the best growth kinetics parameters at $30^{\circ} \mathrm{C}$ in a cultivation of A. microscopica Nägeli, using fish processing waste water as culture medium.

The conversion of substrate into biomass was also favored at $20^{\circ} \mathrm{C}$. Additionally, the yield coefficients values of biomass substrate suggested that A. microscopica Nägeli removes a great amount of organic matter with a low conversion of biomass. Low conversion of organic matter into biomass is characteristic of the heterotrophic microalgae metabolism, where exogenous carbon sources are consumed in the absence of light (FAY, 1983). Conversely, a high conversion of nitrogen into biomass was observed, which qualifies the dairy processing wastewater as a good culture medium to support the microalgal biomass production.

An optimal growth temperature allows the cell growth without modifying any inherent biochemical or physiological parameters, which generally results in a low lipid content in the cells (RAS
\& STEYER, 2013). Therefore, often a stress condition is desired in order to increase the lipid production into the cells. According to the results showed in table 3, the lipid content at temperature of $10^{\circ} \mathrm{C}$ was about $21 \%$ and $32 \%$ higher than observed at $20^{\circ} \mathrm{C}$ and $30^{\circ} \mathrm{C}$, respectively. However, it should be considered that lipid content alone is not a good indicator of suitability for single-cell oil production, as, in general, biomass productivity and lipid content are inversely related. According to QUEIROZ et al. (2011), for selection of the operational conditions in bioreactors for single-cell oil production, the lipid productivity is the main parameter to be considered. Since lipids are intracellular products, the overall lipid productivity is obtained by the amount of lipids of the cell, multiplied by the biomass productivity. Results obtained for lipid productivity showed that the experiments conducted at $20^{\circ} \mathrm{C}$ indicated that the kinetic parameters of growth presented greater influence on the lipid productivity than on lipid content.

Based on these considerations and results, we proposed a two-stage cultivation system in order to find a condition that allows the production of a microalgal biomass with high lipid content without loss of cellular productivity. Results demonstrated that with the cultivation at 
$20^{\circ} \mathrm{C}$ followed by a cold shock at $0^{\circ} \mathrm{C}$ for $24 \mathrm{~h}$, it was possible to obtain a lipid content of $28.4 \%$ with the same biomass productivity of the cultivation at $20^{\circ} \mathrm{C}(160.25 \mathrm{mg} / \mathrm{L} . \mathrm{h})$, which results in a lipid productivity of $45.5 \mathrm{mg} / \mathrm{L} . \mathrm{h}$.

In accordance to literature (XU \& BOEING, 2014), saturation levels exhibited a linear behavior, where the saturated fatty acids (SFA) decreased and the monounsaturated (MUFA) and polyunsaturated fatty acids (PUFA) increased with increasing the cold application. These changes are a consequence of a metabolic adaptation performed to maintain the membrane fluidity at low temperatures. Psychrophilic and psychotropic organisms have the ability of using the extension of unsaturation of the fatty acids in membrane lipids, thus avoiding membrane rigidification at low temperatures. In cyanobacteria, double bonds are introduced into a fatty acid via an aerobic desaturation pathway that acts on membrane lipids (WANG et al., 2016). This reaction is catalyzed by a family of enzymes called desaturases, which are characterized by their ability to convert a single bond in a double bond (LOS \& MURATA, 1999). Similar results were found by CHAISUTYAKORN $\&$ PRAIBOON (2018), where the presence of SFAs in the microalgae Tetraselmis suecica and Nannochloropsis sp. decreased with increasing temperature (from $25^{\circ} \mathrm{C}$ to $40^{\circ} \mathrm{C}$ ), in contrast with PUFAs. With Dunaliella salina, THOMPSON (1996) observed an increase of $20 \%$ in the level of unsaturated lipids with a temperature shift from $30^{\circ} \mathrm{C}$ to $12^{\circ} \mathrm{C}$.

Besides the biochemical pathways of lipid synthesis, the biosorption by cyanobacteria may have contributed to the lipid incorporation into biomass. LEI et al. (2007) reports the significance of the physical adherence or bonding of ions and molecules onto the surface of the biomass. These authors report that the size and morphology of the cell (high surface area to biovolume ratio) directly impact the lipid contents in microalgal biomass. Isolated or combined, all of these mechanisms contribute to the high levels of single-cell oils obtained in this study.

\section{CONCLUSION}

For sustainable production of single cell oils, it will be important to make use of residual sources and recycle as much as possible. Dairy processing wastewater seems a good culture medium to support the growth and single-cell oil production of Aphanotece microscopia Nägeli.
Kinetics of the process was significantly influenced by the growth temperature. The cultivation at $20^{\circ} \mathrm{C}$ was the most appropriate for the production of biomass. Cold shocks were efficient in increasing the lipid productivity, which was increased up to $124.5 \%$ compared to the best cultivation without shock. Cold shocks showed also influence on the saturation of fatty acid composition.

Results indicated that the modulation of temperature shocks is an effective strategy to improve the parameters of single-cell oils production and, consequently, contribute to increase feasibility of cyanobacteria biodiesel production.

\section{ACKNOWLEDGEMENTS}

Funding for this research was provided by $(\mathrm{CNPq})$ National Council for Scientific and Technological Development.

\section{DECLARATION OF CONFLICTING INTERESTS}

The authors declare that the research was conducted in the absence of any commercial or financial relationships that could be construed as a potential conflict of interest.

\section{AUTHORS' CONTRIBUTIONS}

All authors contributed equally for the conception and writing of the manuscript. All authors critically revised the manuscript and approved of the final version.

\section{REFERENCES}

APHA. Standards Methods for the Examination of Water and Wastewater, Washington: American Public Health Association, 1989.

BLIGH, E.G.; DYER, J.W.A. Rapid method of total lipid extraction and purification. Can. J. Biochem. Physiol, v.37, p.911-917, 1959. Available from: <http://www.nrcresearchpress.com/doi/pdf/10.1139/ o59-099>. Accessed: Oct. 21, 2018. doi: 10.1139/059-099.

BREUER, G.; LAMERS, P.P. et al. Opportunities to improve the areal oil productivity of microalgae. Bioresour. Technol, v.186, p.294-302, 2015. Available from: <https://www.sciencedirect.com/ science/article/pii/S0960852415004174>. Accessed: Oct. 21, 2018. doi: 10.1016/j.biortech.2015.03.085.

CHAISUTYAKORN, P.; PRAIBOON, J. et al. The effect of temperature on growth and lipid and fatty acid composition on marine microalgae used for biodiesel production. J. Appl. Phycol, v.29, p.1-9, 2018. Available from: <https://link.springer.com/ article/10.1007/s10811-017-1186-3>. Accessed: Oct. 21, 2018. doi: 10.1007/s10811-017-1186-3.

FAY, P. The blue-greens (Cyanophyta-cyanobacteria). London: Edward Arnold Publishers, 1983.

GRIFFITHS, M.J.; HARRISON, S.T.L. Lipid productivity as a key characteristic for choosing algal species for biodiesel production. 
J. Appl. Phycol, v.21, p.493-507, 2009. Available from: <https:// link.springer.com/article/10.1007/s10811-008-9392-7>. Accessed: Oct. 21, 2018. doi: 10.1007/s10811-008-9392-7.

HARTMAN, L.; LAGO, R.C.A. A rapid determination of fatty acid methyl esters from lipids. Lab. pract., v.22, p.475476, 1976. Available from: <https://www.ncbi.nlm.nih.gov/ pubmed/4727126>. Accessed: Oct. 21, 2018.

HERRERO, A.; MURO-PASTOR, A.M. et al. Nitrogen control in cyanobacteria. J. Bact., v.183, p.411-425, 2001. Available from: $<$ https://www.ncbi.nlm.nih.gov/pubmed/11133933>. Accessed: Oct. 21, 2018. doi: 10.1128/JB.183.2.411-425.2001.

LEI, A.P.; HU, Z.L. et al. Removal of fluoranthene and pyrene by different microalgal species. Bioresour. Technol., v.98, p.273-280, 2007. Available from: <https://www.sciencedirect.com/science/ article/pii/S0960852406000381>. Accessed: Oct. 21, 2018. doi: 10.1016/j.biortech.2006.01.012.

LOS, D.A.; MURATA, N. Responses to Cold Shock in Cyanobacteria. J. Mol. Microbiol. Biotechnol., v.2, p.22130, 1999. Available from: <https://www.ncbi.nlm.nih.gov/ pubmed/10943553>. Accessed: Oct. 21, 2018.

QUEIROZ, M.I.. et al. Single-cell oil production by cyanobacterium Aphanothece microscopica Nägeli cultivated heterotrophically in fish processing wastewater. Appl. Energy., v.88, p.3438-3443, 2011. Available from: <https://www.sciencedirect.com/science/ article/pii/S0306261910005672>. Accessed: Oct. 21, 2018. doi: 10.1016/j.apenergy.2010.12.047.

QUEIROZ, M.I.. et al. Fish processing wastewater as a platform of the microalgal biorefineries. Biosyst. Eng., v.115, p. 195-202, 2013. Available from: <https:/www.sciencedirect.com/science/ article/pii/S1537511012002243>. Accessed: Oct. 21, 2018. doi: 10.1016/j.biosystemseng.2012.12.013Get.

RAS, M.; STEYER, JP. Temperature effect on microalgae: a crucial factor for outdoor production. Rev. Environ. Sci. Bio., v.12, p.153-164, 2013. Available from: <https://link.springer.com/ article/10.1007/s11157-013-9310-6>. Accessed: Oct. 21, 2018. doi: $10.1007 / \mathrm{s} 11157-013-9310-6$.

RIPPKA, R.; DERUELLES, J. et al. Generic assignments strain histories and properties of pure cultures of cyanobacteria. J. Gen. Microbiol., v.111, p.01-61, 1979. Available from:
$<$ http://mic.microbiologyresearch.org/content/journal/ micro/10.1099/00221287-111-1-1>. Accessed: Oct. 21, 2018. doi: 10.1099/00221287-111-1-1.

SUBHASH, G.V. et al. Temperature induced stress influence on biodiesel productivity during mixotrophic microalgae cultivation with wastewater. Bioresour. Technol., v.169, p.789-793, 2014. Available from: <https:/www.sciencedirect.com/science/article/ pii/S0960852414009845?via\%3Dihub>. Accessed: Oct. 21, 2018. doi: 10.1016/j.biortech.2014.07.019.

THOMPSON, G.A. Lipids and membrane function in green algae. Biochim. Biophys. Acta, v.1302, p.17-45, 1996. Available from: $<$ https://www.sciencedirect.com/science/ article/pii/0005276096000458>. Accessed: Oct. 21, 2018. doi: 10.1016/0005-2760(96)00045-8.

TOMASELLI, L.; GIOVANNETTI, L. et al. Effects of temperature on growth and biochemical composition in Spirulina platensis strain M2, in: STADLER, T.; MELLION, J. et al., Algal Biotechnology, London: Elsevier Science, 1988, p. 303-314.

WANG, Y.Z. et al. Growth and lipid accumulation of indigenous algal strains under photoautotrophic and mixotrophic modes at low temperature. Algal Res., v.16, p.195-200, 2016. Available from: $<$ https:// www.sciencedirect.com/science/article/pii/S2211926416300960>. Accessed: Oct. 21, 2018. doi: 10.1016/j.algal.2016.03.017.

WILLERS, C.D.; FERRAZA, S.P. et al. Determination of indirect water consumption and suggestions for cleaner production initiatives for the milk-producing sector in a Brazilian middlesized dairy farming. J. Clean. Prod., v.72, p.146-152, 2014. Available from: <https:/www.sciencedirect.com/science/article/ pii/S0959652614002017>. Accessed: Oct. 21, 2018. doi: 10.1016/j. jclepro.2014.02.055

XU, Y.; BOEING, W.J. Modeling maximum lipid productivity of microalgae: Review and next step. Renew. Sustainable Energy Rev., v.32, p.29-39, 2014. Available from: <https://www. sciencedirect.com/science/article/pii/S1364032114000124>. Accessed: Oct. 21, 2018. doi: 10.1016/j.rser.2014.01.002.

ZHOU, W.; et al. Environment-enhancing algal biofuel production using wastewaters. Renew. Sustainable Energy Rev., v.36, p.256-269, 2014. Available from: <https://www.sciencedirect. com/science/article/pii/S1364032114003116>. Accessed: Oct. 21, 2018. doi: 10.1016/j.rser.2014.04. 